\title{
Towards a novel approach to improve drinking water quality at Dhaka, Bangladesh
}

\author{
Md. Serajuddin ${ }^{\dagger}$, Md. Aktarul Islam Chowdhury \\ Department of Civil \& Environmental Engineering, Shahjalal University of Science \& Technology (SUST), Sylhet, 3114, Bangladesh
}

\begin{abstract}
The river water source of Saidabad Surface Water Treatment Plant at Dhaka, Bangladesh, is deteriorated too much to be treated by conventional treatment process due to excessive ammonia pollution. In order to improve the raw water quality before it enters into the main treatment chain, a pilot study was conducted for pre-treatment of the raw water. The objective is to investigate the rate of reduction of ammonia using the Meteor pilot, a biological pretreatment system, which is a laboratory scale Moving Bed Biofilm Reactor with a nominal volume of hundred liters, filled with $50 \mathrm{~L}$ of Meteor 660 media. The reduction of ammonia was quite significant on average $73 \%$, while the reduction of COD was in a range from 20 to $60 \%$. The Meteor pilot was able to treat and nitrify the raw water and produce an effluent that respects the guarantee of ammonia $<4.0 \mathrm{mg} \mathrm{NH} 3-\mathrm{N} / \mathrm{L}$ when the raw water ammonia concentration was $<15 \mathrm{mg} \mathrm{NH} \mathrm{N}_{3}-\mathrm{N} / \mathrm{L}$. The study identified operating parameters necessary to achieve the desired goal of adequate ammonia removal. The study results would benefit a range of systems across the country by providing guidance on the design and operation of a biological pre-treatment system for ammonia removal.
\end{abstract}

Keywords: Ammonia removal, Biological nitrification, Drinking water treatment, Moving Bed Biofilm Reactor (MBBR), Sitalakhya River raw water

\section{Introduction}

Dhaka, the capital of Bangladesh, at present with a population of 15 million, is almost $78 \%$ dependent on groundwater for its drinking water. The city water Authority in 2004, could supply around 1,950 million liters per day (MLD) of water, out of which $87 \%$ coming from the unsustainable underground source. Once, presumably cheap and abundant, groundwater source inside Dhaka has gradually been depleted so much that no further large extraction is possible technically and economically. There is no other way out but switch over to surface water source. As an inevitable corollary, the water authority has planned to shift at least $50 \%$ of extraction of total supply to surface water sources and accordingly actions are underway for implementing surface water treatment plants [1-3].

Saidabad Water Treatment Plant (SWTP) phase I was constructed with a capacity of $225 \mathrm{MLD}$, the largest water treatment plant in the country and put into operation on July 27, 2002 [4]. The Sitalakhya River at the eastern periphery of Dhaka city is the source of raw water for the SWTP (Fig. 1). A replication of a similar plant with the same size and design is underway for the second phase, where the third phase of 450 MLD of water is postulated in near future [1].

Sitalakhya River is now facing serious problems due to man-made pollution. In the dry season, there are complaints of bad smell and colour in the supplied treated water extracted from the Sitalakhya. Over viewing at the available data and the complex water quality situation it has been said by the experts that the observed problem of taste, smell and colour of the treated water during the dry seasons, is due to a combination of many cause-effect relations, like high ammonia concentration $\rightarrow$ difficult to disinfect $\rightarrow$ not possible to control algae fully nor to ensure the hygienic quality of water $\rightarrow$ limitations of conventional treatment process [5].

The SWTP phase-I operational data show a clearly increasing trend of the monthly average and maximum values of ammonia, both increasing around three mg $\mathrm{NH}_{4}-\mathrm{N} / \mathrm{L}$ over the four-year period from 2002 to 2006 [6]. Compared with the initial operating criteria for SWTP I of maximum $4 \mathrm{mg} \mathrm{NH}_{4}-\mathrm{N}$ per liter and with the Bangladesh Standard for Nitrate of $10 \mathrm{mg} \mathrm{NO}-\mathrm{N}$, the increases are substantial in such a short period and the trend must be taken into consideration [6].
This is an Open Access article distributed under the terms of the Creative Commons Attribution Non-Commercial License (http://creativecommons.org/licenses/by-nc/3.0/) which permits unrestricted non-commercial use, distribution, and reproduction in any medium, provided the original work is properly cited.
Received July 16, 2017 Accepted October 19, 2017

${ }^{\dagger}$ Corresponding author

Email: serajdwasa@gmail.com

Tel: $+880-1817575372$

Copyright (C) 2018 Korean Society of Environmental Engineers 


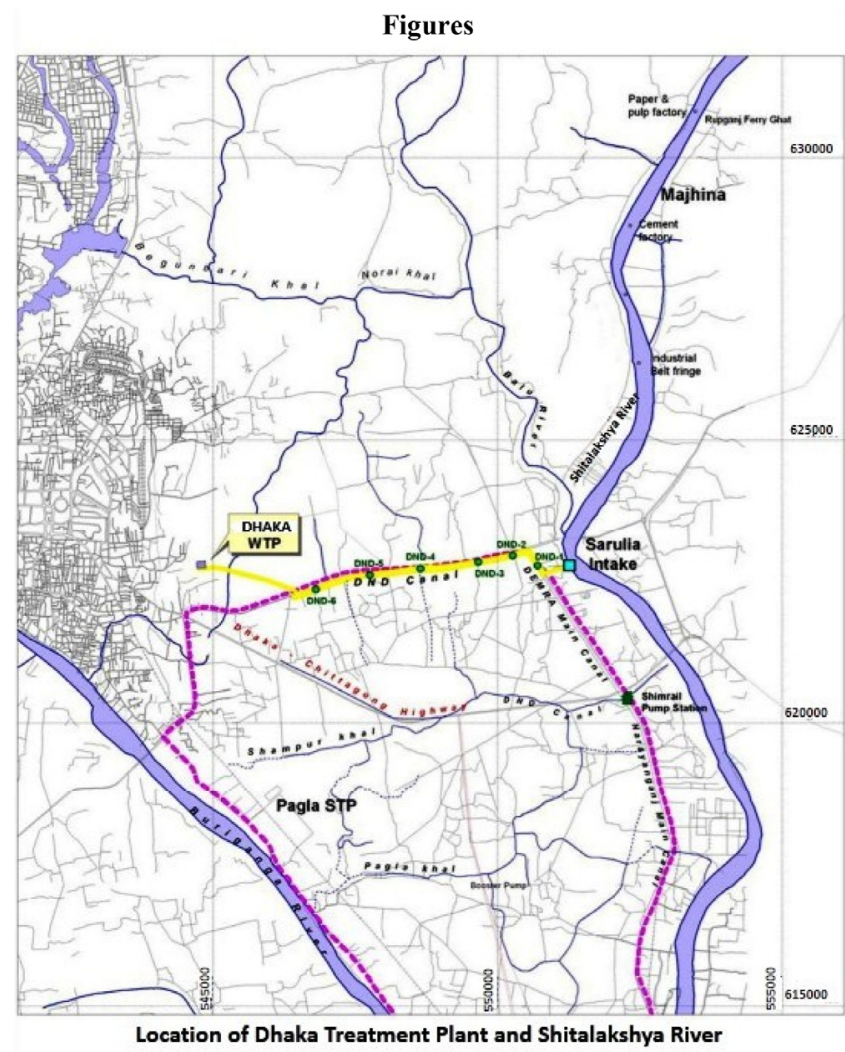

Fig. 1. Raw water source and its transmission network from Sitalakhya River to WTP.

During formulation of SWTP phase-II project with the idea of pre-treatment of raw water, three probable options were discussed, namely: Stripping of ammonia, breakpoint chlorination, nitrification and de-nitrification, if needed. The experts proposed Moving Bed Biofilm Reactor (MBBR), prior to conventional treatment chain, as an option of pre-treatment which might be an economic and effective treatment process to remove pollutants from raw water [6-9].

The MBBR, first invented by Prof. Hallvard Ødegaard at Norwegian University of Science and Technology and was developed (Eur. pat. no. 0575314, US pat. no. 5,458,779) in the late 1980s, in Norway on the basis of conventional activated sludge and bio-filter process [10]. Quite large numbers of literature are available on the use of biofilm reactor for the treatment of wastewater [11-19]. There are presently more than 400 large-scale wastewater treatment plants based on this process in operation in 22 different countries all over the world [13]. However, this innovative biofilm reactor has not been introduced for the pre-treatment of drinking water [19]. There is very little information in the literature on the use of biological drinking water treatment particularly on the use of MBBR [20-24]. It has been said that "Biological filtration has not been historically accepted, at least not in North America” [21].

With such backdrops, before taking the crucial and revolutionary decision of a full-scale biological pre-treatment unit for a drinking water plant in Dhaka to mitigate pollution load of drinking water, a pilot study was conducted as a feasibility with a laboratory scale MBBR to pre-treat the raw water of the Sitalakhya River, the source raw water of the largest treatment plant in the country [25].

\subsection{Objective of the Study}

The objective of the present study is to investigate primarily the rate of reduction of raw water ammonia and the specific operating conditions of a particular source in a specific site using the Meteor pilot, as it is named, a biological pre-treatment system, which is a laboratory scale MBBR. It was intended to get some notions regarding its potential, as indicated by some manufacturer, in providing a tangible \& sustainable solution to those difficult challenges encountered in Dhaka water. Reduction of COD and raw water oxygen demands were also evaluated in detail. The outcome of this study would be very useful and fundamental data for the design of future water supply project in Dhaka taking the Sitalakhya River water as the raw water source given that this biological process appears to be potential at this location. The other factors those affect the efficacy of a biological treatment like time since start-up, temperature, pollution loading rate, oxygen level required, resulting oxygen in the pre-treated water, hydraulic retention time (HRT), pH, sudden shock of pollution loading (like the increase in ammonia load from $0.5 \mathrm{mg} \mathrm{NH}{ }_{4}^{+} / \mathrm{L}$ to $6-10 \mathrm{mg}$ corresponding to an increase in load of a factor $12-20$ within a month), etc. were also noted.

\section{Materials and Methods}

\subsection{Experimental Setup (Meteor Pilot Unit)}

A pilot scale MBBR known as Meteor was used to investigate the feasibility of biological pretreatment of Sitalakhya River water. The pilot was built in a circular cylindrical shape reactor having a diameter of $400 \mathrm{~mm}$ \& height of $1,200 \mathrm{~mm}$ as well as an effective volume of $100 \mathrm{~L}$ and made of transparent plastic (Fig. 2).

The study was carried out in the water testing laboratory of SWTP. The raw water was taken from the intake point of SWTP and the water testing facility in the SWTP laboratory was utilized for the study from February 9 to June 9 in 2011.

The laboratory scale Meteor pilot with a nominal volume of $100 \mathrm{~L}$ was filled with 50 liters of the 'Meteor 660 media' as it is called (Fig. 2 \& 3). The description of prime characteristic features of media are as follows: the shape is corrugated cylindrical with colour black, the surface area of the media is $650 \mathrm{~m}^{2} / \mathrm{m}^{3}$, nominal diameter and length is $12 \mathrm{~mm}$, bulk density $146 \mathrm{~kg} / \mathrm{m}^{3}$, filling rate $50 \%$, material is a high density poly ethylene, the specific gravity is 0.95 . The reactor is equipped with one Flexazur fine bubble aeration tube (length: $35 \mathrm{~cm}$ ) (Fig. 2), a raw water inlet pipe and a treated water effluent pipe fitted with a media retention screen (Fig. 3). The aeration is located on one side at the bottom of the reactor to create a spiral flow and thus provide primary function of oxygen transfer and mixing to ensure a full utilization of the reactor volume by making each small element in the media following the circulation of the waterand a uniform dispersion of dissolved oxygen throughout the mixed liquor of the reactor. The raw water coming from the inlet of the water treatment plant is pumped at a controlled rate into the bottom of the reactor, 


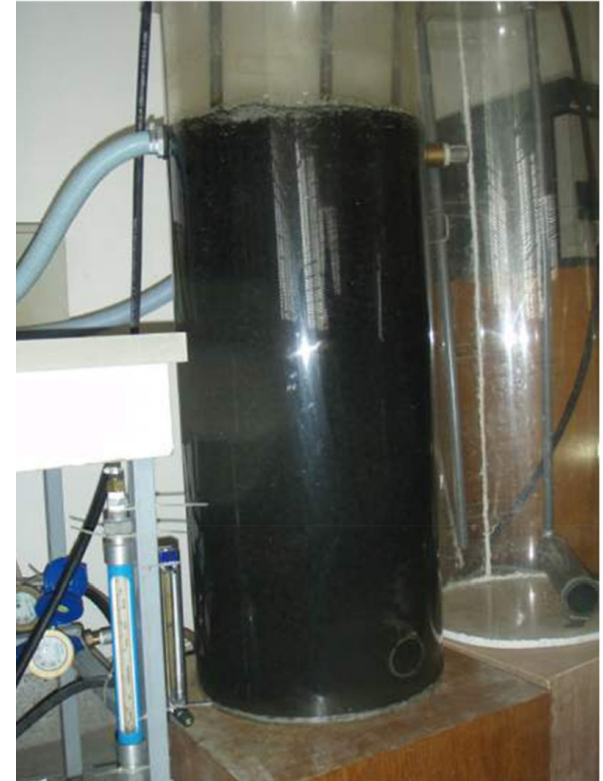

Fig. 2. Experimental setup of Meteor pilot unit \& flow diagram.
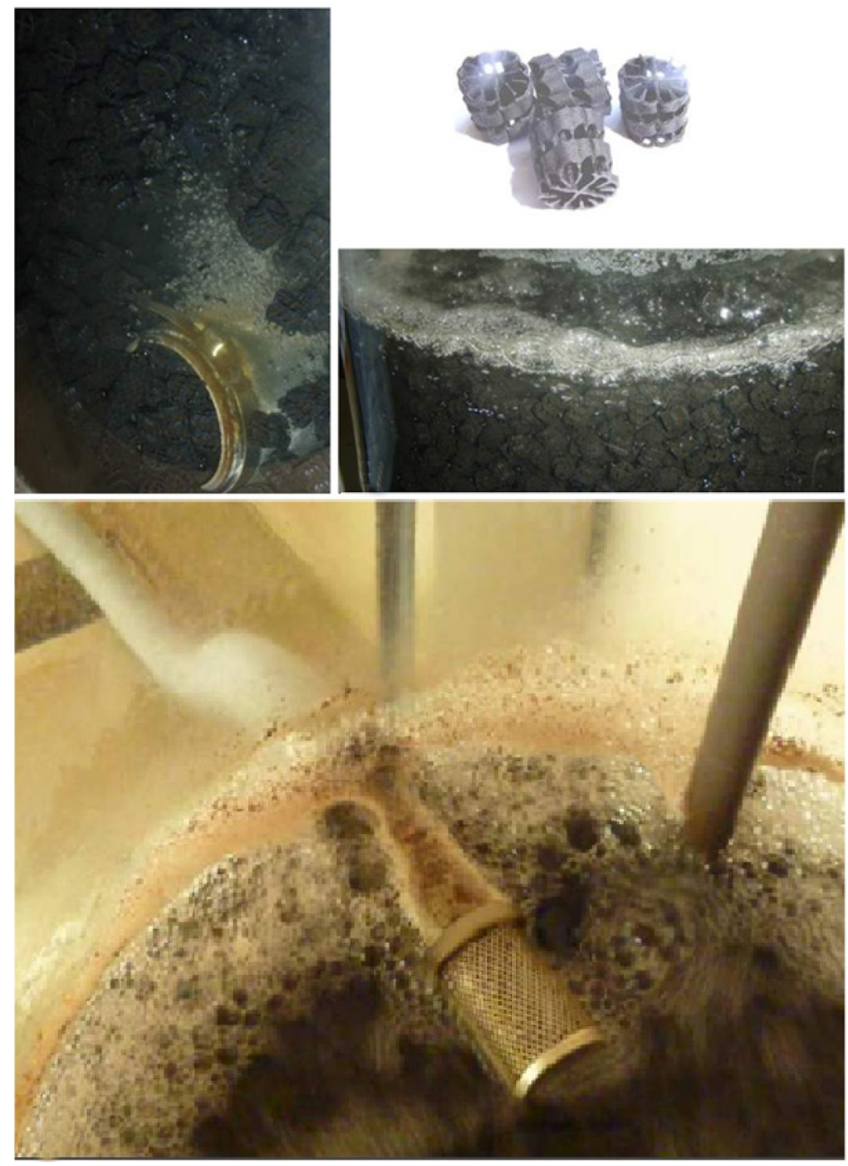

Fig. 3. Meteor 360 media, pilot effluent pipe with media retaining screen.

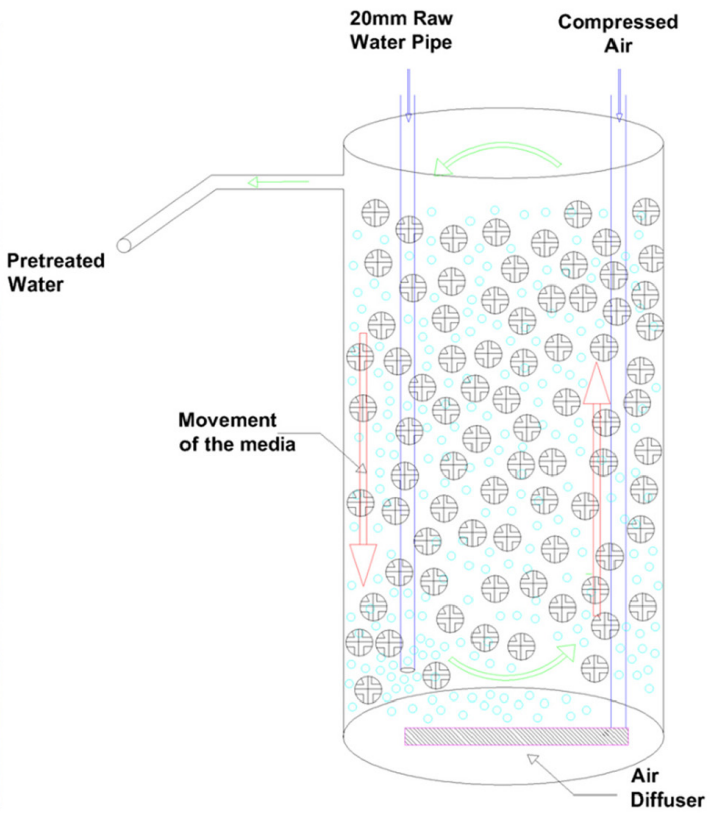

and the effluent leaves the reactor through the media retaining screen and flows by gravity to a drain in the laboratory. The range of flow rate was controlled from 0.5 to $2.0 \mathrm{~L} / \mathrm{min}$, with a few excursions to slightly higher flows $(3.0 \mathrm{~L} / \mathrm{min})$. A flow rate of $2.0 \mathrm{~L} / \mathrm{min}$ corresponds to the targeted full-scale Meteor design hydraulic retention time of $50 \mathrm{~min}$. Compressed air is fed to the diffuser at rates from 6 to $40 \mathrm{~L} / \mathrm{min}$, depending on the loading rates and dissolved oxygen measurements. No external organic source other than the feed water was added in the pilot from outside. The average concentration of sulfide and phosphate in the raw water during the study was found to be $0.04 \mathrm{mg} / \mathrm{L}$ and $0.53 \mathrm{mg} / \mathrm{L}$, respectively. The concentration of expected major quality parameter of the raw water are as follows, $\mathrm{NH}_{4} / \mathrm{N}$ : $(10-15 \mathrm{mg} / \mathrm{L})$, COD: (20-60 mg/L), BOD: (15-40 mg/L), Turbidity: $15 \mathrm{mg} / \mathrm{L}, \mathrm{pH}$ : (6.5-8.5), DO: (1-3 mg/L), $\mathrm{NO}_{3}$ : (0.2-4.2 mg/L), $\mathrm{PO}_{4}$ : (0.3-4.9 mg/L), sulfide: $(6-25 \mathrm{mg} / \mathrm{L})$, Temperature: $\left(20-30^{\circ} \mathrm{C}\right)$ and the targeted pre-treated raw water ammonia concentration is $<4 \mathrm{mg} / \mathrm{L}$. The operating condition is briefly presented in Fig. 4 through Fig. 10.

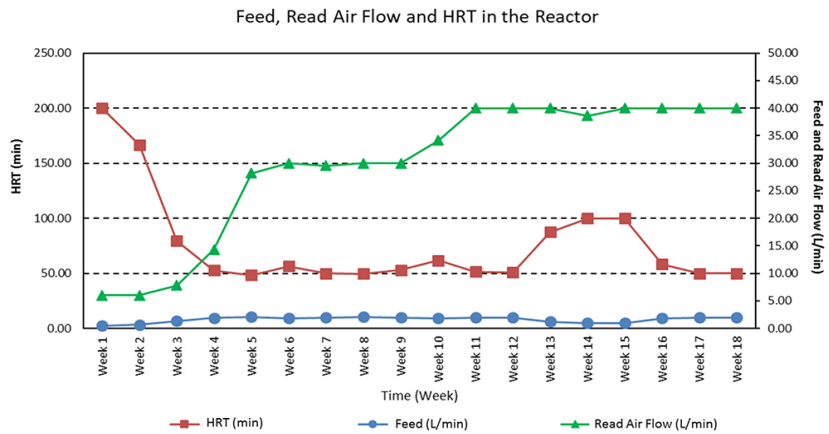

Fig. 4. Weekly average of feed, air flow \& hydraulic retention time (HRT) in the reactor. 


\subsection{Water Testing and Laboratory Analysis.}

The water quality investigation was performed in the water testing laboratory of SWTP. Some supplementary analysis was done in the laboratory of Civil Engineering Laboratory of Bangladesh University of Engineering and Technology, Bangladesh. The internationally accepted methods of sampling and testing like APHA were used in the investigation, for example ammonia was tested by using HACH DR 6000 spectrophotometer (HACH LANGE, USA) \& Nessler method, No. 8038; COD was tested using HACH DR 890 colorimeter (HACH LANGE, USA), HACH DRB200 COD reactor (HACH LANGE, USA) \& by reactor digestion method No. 8000, Turbidity was measured using HACH 2100Q Turbidity meter (HACH LANGE, USA) \& by nephelometric method, etc.

\section{Results and Discussion}

\subsection{Start-up Period}

The pilot unit operation started on February 9, 2011, at a feed flow rate of $0.5 \mathrm{~L} / \mathrm{min}(\mathrm{HRT}=3.3 \mathrm{~h})$, with a process air flow rate of $6 \mathrm{~L} / \mathrm{min}$, which was sufficient to provide adequate mixing \& transfer of oxygen. Progressively the nitrification process began and the effluent ammonia concentration decreased to below 2.0 mg $\mathrm{NH}_{3}-\mathrm{N} / \mathrm{L}$ within $12 \mathrm{~d}$. Thus the nitrification biofilm was developed on the media and the process established within a period of two weeks. By March 06 the pilot was operating consistently at the design flow of $2.0 \mathrm{~L} / \mathrm{min}$.

The process air was also increased progressively from 6 to 12 and eventually up to $30 \mathrm{~L} / \mathrm{min}$ [4]. The immediate response to the increased air on March 08 was a decrease in the effluent $\mathrm{NH}_{3}-\mathrm{N}$ to $<4.0 \mathrm{mg} / \mathrm{L}$, demonstrating that the oxygen was a limiting factor for the initial days when running at the design water flow rate of $2.0 \mathrm{~L} / \mathrm{min}$. The intended removal of $11 \mathrm{mg} \mathrm{NH}_{3}-\mathrm{N} / \mathrm{L}$ was achieved by $27 \mathrm{~d}$ of operation when there was sufficient oxygen for the process [Fig. 5]. Overall, the required time to achieve the maximum targeted ammonia removal rates is less than four weeks, and if sufficient air would have been provided the required time might be less, in the order of three weeks.

In general, the start-up of the Meteor process will coincide with the beginning of the dry-season at Dhaka, which will occur

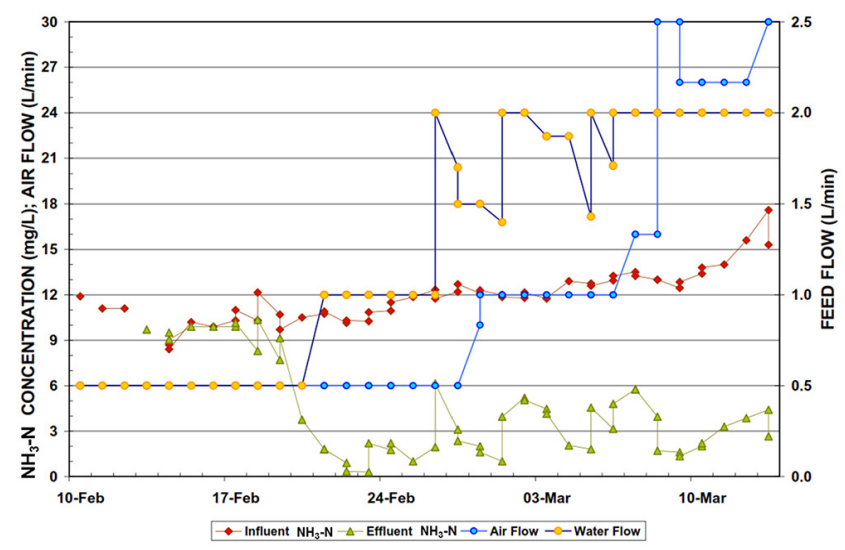

Fig. 5. Ammonia concentrations during start-up. at the beginning of December, and the raw water ammonia concentrations expected to be in the range of 2 to $4 \mathrm{mg} / \mathrm{L}$ and progressively increase to 6 to $8 \mathrm{mg} / \mathrm{L}$ during a period of eight weeks. The results from the pilot study show that starting with virgin media the process will be able to follow this increase in ammonia loading. For a situation where the process needs to start in the middle of the dry-season (high ammonia concentrations $>10 \mathrm{mg} / \mathrm{L}$ ), the process can be expected to reach design removal rates after a period of approximately three weeks.

\section{2. $\mathrm{NH}_{3}-\mathrm{N}$ Removal}

During the initial period, after the start-up was achieved, the Meteor was able to remove $11 \mathrm{mg} / \mathrm{L}$ at the design flow (Fig. 6). During the period from March 29 through May 5, the pilot run at 2.0 $\mathrm{L} / \mathrm{min}$ (except for days when there were issues with the feed flow control) and the raw water ammonia concentrations are found in the upper range: 10 to $17 \mathrm{mg} / \mathrm{L}$. This period demonstrates the full capacity of the process, with average removed ammonia of $11 \mathrm{mg} / \mathrm{L}$, and a maximum removal of $13.5 \mathrm{mg} / \mathrm{L}$. During this period the effluent $\mathrm{NH}_{3}-\mathrm{N}$ is maintained below $4.0 \mathrm{mg} / \mathrm{L}$ (excluding the days when feed flow rate is $>2.0 \mathrm{~L} / \mathrm{min}$ ), with an average effluent $\mathrm{NH}_{3}-\mathrm{N}$ of $1.7 \mathrm{mg} / \mathrm{L}$ (excluding days when feed flow rate is not $2.0 \mathrm{~L} / \mathrm{min}$ ) (Fig. 6). The organic concentration (cBOD, soluble cBOD) in the raw and pretreated water is shown in Fig. 7. The dissolved oxygen concentrations in the feed and effluent water are shown

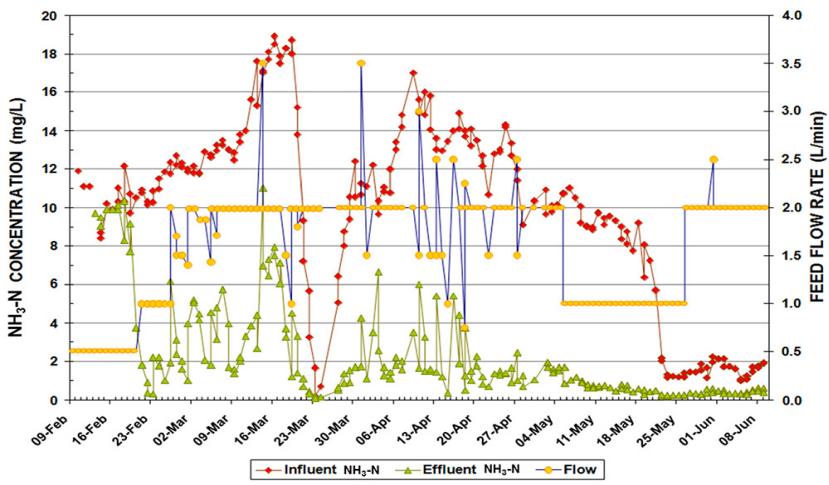

Fig. 6. Influent and effluent $\mathrm{NH}_{3}-\mathrm{N}$ concentration \& feed flow during study.

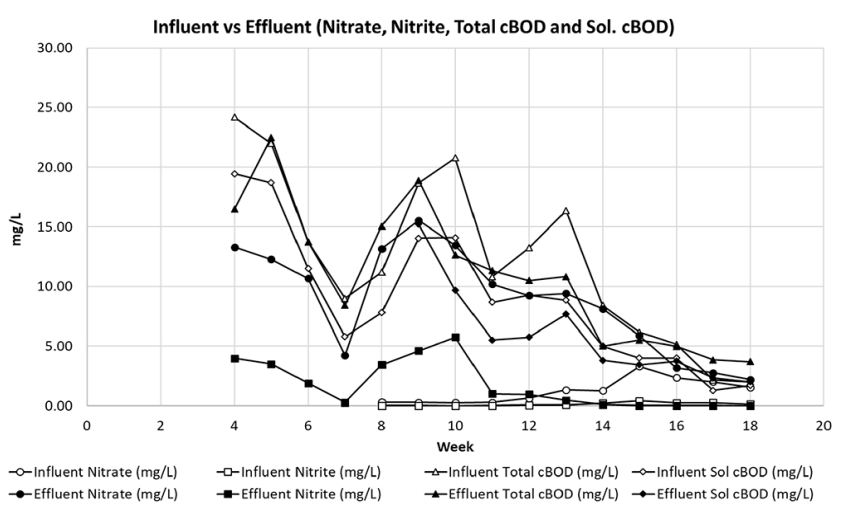

Fig. 7. Weekly average of nitrate, nitrite, total CBOD \& sol.cBOD in the influent \& effluent. 


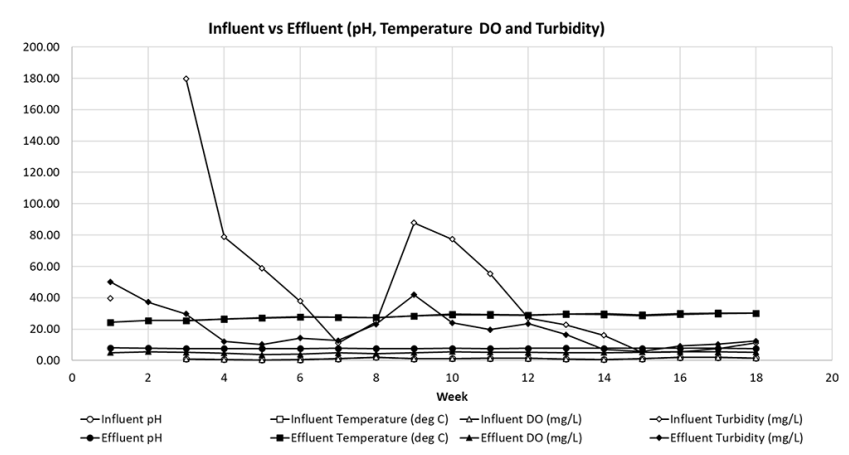

Fig. 8. Weekly average of $\mathrm{pH}$, temperature, $\mathrm{DO} \&$ turbidity in the influent and effluent.

in Fig. 8. During the pilot study, the influent strength was $\mathrm{NH}_{3}-\mathrm{N}$ $>15 \mathrm{mg} / \mathrm{L}$ for $20 \mathrm{~d}$, and the amount of $\mathrm{NH}_{3}-\mathrm{N}$ removed was > $11 \mathrm{mg} / \mathrm{L}$ for $42 \mathrm{~d}$.

\subsection{COD Removal and Raw Water Oxygen Demand}

The raw water total COD varied significantly during the study, from $10 \mathrm{mg} / \mathrm{L}$ to $80 \mathrm{mg} / \mathrm{L}$ (Fig. 9), with similar general trends in the variation of concentration as the ammonia. The average ratio of soluble/total COD in the raw water is $79 \%$, which is higher than typical for municipal wastewaters.

The COD removal based on the influent total COD minus the effluent soluble COD provides a calculation of the maximum amount of carbonaceous pollution removed in the Meteor pilot unit. It also represents the maximum overall oxygen consumed for the oxidation of pollutants in the raw water other than ammonia. Fig. 9 shows the total raw water COD, effluent soluble COD and a calculated COD removal (the difference between these two values) during the period when these analyses were made. During the period from 12 April through 21 May, the COD removal was in a range from 13 to $52 \mathrm{mg} / \mathrm{L}$, with $4 \mathrm{~d}$ having COD removal in the range from 30 to $50 \mathrm{mg} / \mathrm{L}$. Thus the biological process was able to remove more carbonaceous pollution than the feasibility report and at the same time remove the required ammonia load. It is notable that there still remains 10 to $40 \mathrm{mg} / \mathrm{L}$ of soluble COD which is not removed by the biological treatment because this fraction of the COD is non-biodegradable. The very high ratio of $\mathrm{COD} / \mathrm{BOD}$ in the raw water ( 5 on average) also indicates that the water is not very biodegradable. Therefore, the results demonstrate that there are also some forms of dissolved pollution present in the raw water which cannot be removed by biological treatment.

These results show that the oxygen demand of the raw water (not including the ammonia oxygen demand) exceeds the limit of $30 \mathrm{mg} / \mathrm{L}$ indicated in the feasibility study [5]. Since the measured levels of sulfide in the raw water were insignificant, this means that the level of carbonaceous pollutants is higher than expected. The results also show that oxygen demands will be higher than $30 \mathrm{mg} / \mathrm{L}$ for carbonaceous pollutants during periods of peak pollution coinciding with the peak ammonia concentrations. No significant level of sulfides was found in the raw water or treated water, therefore the target of $<0.1 \mathrm{mg} / \mathrm{L} \mathrm{S}^{2}-/ \mathrm{L}$ in the effluent was easily achieved. A comparison of the actual oxygen consumed in the pilot study (due to both COD and ammonia removal) and

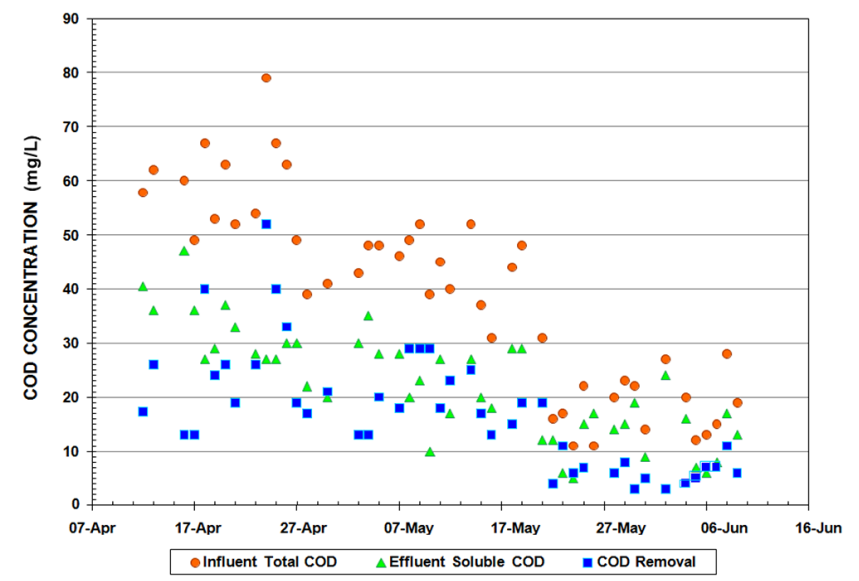

Fig. 9. COD removal.

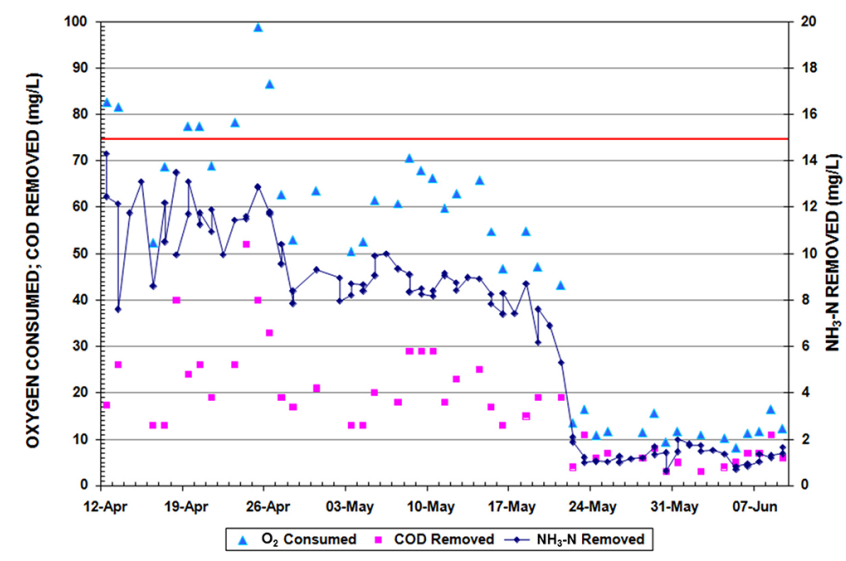

Fig. 10. Oxygen consumption, COD \& ammonia removal.

the estimated oxygen demand value for the Meteor process demonstrate that during the peak pollution period in April 2011 the raw water exerted a higher oxygen demand than the targeted full-scale design. Noted that the full-scale design oxygen demand, based on the feasibility study, is $75 \mathrm{mg} / \mathrm{L}$ ( $30 \mathrm{mg} / \mathrm{L}$ for carbonaceous pollutants and sulfides $+45 \mathrm{mg} / \mathrm{L}$ for ammonia removal) [5]. Fig. 10 plots both the COD and ammonia removal during the period of April 11 through the end of the study, including the total oxygen consumption values based on: $\mathrm{mg} / \mathrm{L}$ COD removed $+4.57 \times \mathrm{mg}$ $\mathrm{NH}_{3}-\mathrm{N} / \mathrm{L}$.

Seven days surpass the maximum expected value of $75 \mathrm{mg} / \mathrm{L}$ of oxygen and reach a maximum value of $99 \mathrm{mg} / \mathrm{L}$. No similar COD data is available for the largest pollution peak in March; however during the periods of raw water ammonia concentrations above $15 \mathrm{mg} / \mathrm{L}$ the oxygen demand (to remove the COD and the ammonia down to $4.0 \mathrm{mg} / \mathrm{L}$ ) will be above the expected $75 \mathrm{mg} / \mathrm{L}$. During these periods, the aeration will be a limiting factor and may not allow the removal of more than the design ammonia load.

\section{Conclusions}

A laboratory scale pilot MBBR, called Meteor pilot, was used for 
biological pre-treatment of Sitalakhya raw water in this study. The targeted removal of $11 \mathrm{mg} / \mathrm{L}$ of ammonia was possible with an air feed of $40 \mathrm{~L} / \mathrm{min}$. It took three weeks to fully develop the system and full scale start up since commissioning. At the beginning the ammonia concentration was low with low removal rate. Along with ammonia the process can remove COD also from the raw water. But COD will compete with the ammonia. There must be provision of adequate time in the full scale treatment plant for necessary time to establish the nitrification process to start up fully. It will be risky in the context of quality to start the pre-treatment at the middle of the dry season with high ammonia content in raw water. The period of high ammonia in the raw water coincides with the period of high COD demanding more oxygen than anticipated for ammonia alone. During the periods when the oxygen supply is a limiting factor, due to the probable excessive pollution in the raw water, the following negative impacts on the biological process performance and WTP are likely to occur:

- The ammonia in the pretreatment effluent will be $>4.0 \mathrm{mg} / \mathrm{L}$, thus overloading the chlorination capacity of the WTP. An unstable nitrification process due to ammonia overloading, and lack of oxygen, will produce nitrite $\mathrm{NO}_{2}{ }^{-} \mathrm{N}$, which will exert a chlorine demand and overload the chlorination capacity of the WTP.

- Excessive residual soluble COD pollution will not be removed in the WTP and can interfere with the operation and performance of the WTP.

- As expected, during the periods of peak ammonia concentration in the raw water, the amount of ammonia nitrified and thus nitrate produced would be $>10 \mathrm{mg} \mathrm{NO}_{3}-\mathrm{N} / \mathrm{L}$, exceeding the nitrate standard for drinking water.

- The raw water at Saidabad seems to have a fairly high alkalinity - especially during the dry season $(150-250 \mathrm{mg} / \mathrm{L})$. It is therefore unlikely that addition of chemicals becomes necessary.

Pre-treatment would be an option, but not an ideal one, since the removal of organic matter and sulfide needs to be done simultaneously and de-nitrification will soon be needed in the process. The economic \& financial analysis including the opportunity cost of the total system should be assessed as a part of the feasibility.

Pollution control, in the long run, is the optimal solution for Dhaka water in all respect.

\section{Acknowledgments}

A number of advisers and technical personnel were involved in the development \& implementation of the biological nitrification pilot plant from M/s Degremont of France and this cooperation is greatly appreciated.

\section{References}

1. Serajuddin M, Rahman MM. Sustainable water supply: A tale of a megacity. In: International Symposium on Environmental Degradation and Sustainable Development ISEDSD 2010; 10-11 April 2010; BUET, WEDC, British Council.

2. Serajuddin M. Issues and challenges of water supply for a safer megacity - perspective Dhaka. In: National Seminar on Engineers Role in Developing a Safer Megacity; 20 December 2009; Dhaka Centre, the Institution of Engineer's, Bangladesh.

3. IWM. Assessment of the water quality of Lakhya River with special reference to the intake point of Saidabad water treatment plant. Draft Final Report; 2005.

4. Serajuddin M. Water Treatment at Saidabad Plant: State-of-the Art. 'Engineering News' Institution of Engineers, Bangladesh (IEB), Vol. 28, No. 4, July-August 2002.

5. DWASA. Joint feasibility study of pre-treatment for water supply for the Saidabad water treatment plant, Dhaka, Bangladesh, Conducted by Grontmij/CarlBro, Final Report; 2007.

6. Serajuddin M. Issue of raw water quality in the treatment of drinking water at Dhaka. In: Proceedings of the ICETCESD 2011, SUST, Bangladesh, 2011.

7. Pastorelli G, Andreottola G. Pilot plant experiments with moving bed biofilm reactors. Water Sci. Technol. 1997;36:43-50.

8. Rusten B, Siljudlen JG, Strand H. Upgrading of a biological-chemical treatment plant for cheese factory waste water. Water Sci Technol. 1996;34:41-49.

9. Aspegren H, Nyberg U, Andersson B, Gotthardsson S, Jansen JC. Post denitrification in a moving bed biofilm reactor process. Water Sci. Technol. 1998;38:31-38.

10. Ødegaard H, Rusten B, Westrum T. A new moving bed biofilm reactor - Applications and results. Water Sci. Technol. 1994;29:157-165..

11. Ødegaard H. Innovations in wastewater treatment: The moving bed biofilm process. Water Sci. Technol. 2006;53:17-33.

12. Chen S, Sun D, Chung JS. Simultaneous removal of COD and ammonium from landfill leachate using an anaerobic-aerobic moving-bed biofilm reactor system. Waste Manage. 2008;28:339-346.

13. Rusten B, Eikebrokk B, Ulgenes Y, Lygren E. Design and operations of the Kaldnes moving bed biofilm reactors. Aquacult. Eng. 2006;34:322-331.

14. Gulhane ML, Kotangale AJ. Moving bed biofilm reactor - New innovation in the field of conventional biological wastewater treatment. Int. J. Sci. Res. 2013;2:54.

15. Stuart Palmer. Report on research literature related to moving bed biofilm reactor wastewater treatment Deakin University, Waurn Ponds, Vic. March 2013.

16. Ahmadi M. Alavi N, Jaafarzadeh N, Ghaedrahmat Z, Hashemi F. Performance evaluation of moving bed bio film reactor in saline wastewater treatment. Iran. J. Health Sci. 2013;1:58-64.

17. Qiqi Y, Qiang H, Ibrahim HT. Review on moving bed biofilm processes. Pakistan J. Nutr. 2012;11:706-713.

18. Kermani M, Bina B, Movahedian H, Amin MM, Nikaein M. Application of moving bed biofilm process for biological organics and nutrients removal from municipal wastewater. Am. J. Environ. Sci. 2008;4:682-689.

19. Xie SG, Tang XY, Wu WZ, Wen DH, Wang ZS. Biological pre-treatment of Yellow River water. J. Environ. Sci. (China) 2005; 17:557-561.

20. Evans PJ, Opitz EM, Daniel PA, Schulz CR. Biological drinking water treatment perceptions and actual experiences in North America. Water Research Foundation and Department of Defense. Washington D.C., USA; 2010.

21. Takó S. Ammonium removal from drinking water - 
Comparison of the breakpoint chlorination and the biological technology. Conference of Junior Researchers in Civil Engineering; 2012.

22. Bouwer EJ, Crowe PB. Biological processes in drinking water treatment. J. Am. Water Works Assoc. 1988;80:82-93.

23. Rittmann BE, Snoeyink VL. Achieving biologically stable water. J. Am. Water Works Assoc. 1984;76:106-114.

24. Lytle DA, Williams D, Muhlen C, et al. Engineering design and operation report: Biological treatment process for the removal of ammonia from a small drinking water system in Iowa: Pilot to full-scale. USEPA 2014 Sept. EPA/600/R-14/336 | September.

25. Serajuddin M. Biological pre-treatment of the Sitalakhya River water at Dhaka: A pilot study on ammonia removal. In: Proceedings of the ICACE 2012, CUET, Bangladesh; 2011. 